\title{
Front Matter: Volume 6463
}

, "Front Matter: Volume 6463," Proc. SPIE 6463, Reliability, Packaging, Testing, and Characterization of MEMS/MOEMS VI, 646301 (19 January 2007); doi: 10.1117/12.725139

Event: MOEMS-MEMS 2007 Micro and Nanofabrication, 2007, San Jose, California, United States 


\title{
PROCEEDINGS OF SPIE
}

\section{Reliability, Packaging, Testing, and Characterization of MEMS/MOEMS VI}

\author{
Allyson L. Hartzell \\ Rajeshuni Ramesham \\ Chairs/Editors
}

23-24 January 2007

San Jose, California, USA

Sponsored and Published by

SPIE-The International Society for Optical Engineering

Volume 6463

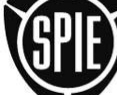

The International Society

for Optical Engineering 
The papers included in this volume were part of the technical conference cited on the cover and title page. Papers were selected and subject to review by the editors and conference program committee. Some conference presentations may not be available for publication. The papers published in these proceedings reflect the work and thoughts of the authors and are published herein as submitted. The publisher is not responsible for the validity of the information or for any outcomes resulting from reliance thereon.

Please use the following format to cite material from this book:

Author(s), "Title of Paper," in Reliability, Packaging, Testing, and Characterization of MEMS/MOEMS VI, edited by Allyson L. Hartzell, Rajeshuni Ramesham, Proceedings of SPIE Vol. 6463 (SPIE, Bellingham, WA, 2007) Article CID Number.

ISSN 0277-786X

ISBN 9780819465764

Published by

\section{SPIE-The International Society for Optical Engineering}

P.O. Box 10, Bellingham, Washington 98227-0010 USA

Telephone 1 360/676-3290 (Pacific Time) · Fax 1 360/647-1445

http://www.spie.org

Copyright (@) 2007, The Society of Photo-Optical Instrumentation Engineers

Copying of material in this book for internal or personal use, or for the internal or personal use of specific clients, beyond the fair use provisions granted by the U.S. Copyright Law is authorized by SPIE subject to payment of copying fees. The Transactional Reporting Service base fee for this volume is $\$ 15.00$ per article (or portion thereof), which should be paid directly to the Copyright Clearance Center (CCC), 222 Rosewood Drive, Danvers, MA 01923. Payment may also be made electronically through CCC Online at http://www.copyright.com. Other copying for republication, resale, advertising or promotion, or any form of systematic or multiple reproduction of any material in this book is prohibited except with permission in writing from the publisher. The CCC fee code is 0277-786X/07/\$15.00.

Printed in the United States of America. 


\section{Contents}

vii Conference Committee

ix Introduction

\section{SENSORS: APPLICATIONS AND RELIABILITY METHODOLOGY}

646302 Receptor-free nanomechanical sensors (Keynote Paper) [6463-01]

L. R. Senesac, D. Yi, T. Thundat, Oak Ridge National Lab. (USA)

646303 New techniques for detecting and monitoring corrosion using nanostructures (Invited Paper) [6463-02]

C. O. Muller, W. G. England, Purafil, Inc. (USA)

646304 Hybrid approach to MEMS reliability assessment [6463-03]

J. L. Zunino III, D. R. Skelton, U.S. Army RDE Command (USA); W. Han, R. J. Pryputniewicz,

WPI-ME (USA)

\section{RF MEMS AND RELATED FAILURE MECHANISMS}

646305 Metal contact reliability of RF MEMS switches (Invited Paper) [6463-04]

Q. Ma, Q. Tran, T.-K. A. Chou, J. Heck, H. Bar, R. Kant, V. Rao, Intel Corp. (USA)

646306 Effects of $\mathrm{V}$ additions on the mechanical behavior of Au thin films for MEMS contact switches [6463-05]

T. Bannuru, Lehigh Univ. (USA); S. Narksitipan, Chiang Mai Univ. (Thailand); W. L. Brown,

R. P. Vinci, Lehigh Univ. (USA)

646307 Mechanics of thin film adhesion-delamination subjected to residual stress and interfacial adhesion: application to MEMS-RF-switch [6463-06]

M. F. Wong, K.-T. Wan, Univ. of Missouri-Rolla (USA)

Pagination: Proceedings of SPIE follow an e-First publication model, with papers published first online and then in print and on CD-ROM. Papers are published as they are submitted and meet publication criteria. A unique, consistent, permanent citation identifier (CID) number is assigned to each article at the time of the first publication. Utilization of CIDs allows articles to be fully citable as soon they are published online, and connects the same identifier to all online, print, and electronic versions of the publication.

SPIE uses a six-digit CID article numbering system in which:

- The first four digits correspond to the SPIE volume number.

- The last two digits indicate publication order within the volume using a Base 36 numbering system employing both numerals and letters. The CID number appears on each page of the manuscript. The complete citation is used on the first page, and an abbreviated version on subsequent pages. 
646309 A novel technique for extraction of material properties through measurement of pull-in voltage and off-capacitance of beams [6463-09]

J. Sharma, A. DasGupta, Indian Institute of Technology, Madras (India)

64630A Cyclic thin film flexible pressure sensor testing [6463-10]

H. C. Lim, New Jersey Institute of Technology (USA); J. L. Zunino III, U.S. Army ARDEC (USA);

J. F. Federici, New Jersey Institute of Technology (USA)

64630B Self-sensing and actuation of CNF and Ni nanowire/polymer composites using electromicromechanical test [6463-11]

J.-M. Park, Gyeongsang National Univ. (South Korea) and Univ. of Utah (USA); S.-J. Kim,

P.-G. Kim, Gyeongsang National Univ. (South Korea); D.-J. Yoon, Korea Research Institute of Standard and Science (South Korea); G. Hansen, Metal Matrix Composites Inc. (USA);

K. L. DeVries, Univ. of Utah (USA)

64630C Critical comparison of metrology techniques for MEMS [6463-12]

M. G. da Silva, Exponent Inc. (USA); S. Bouwstra, MEMS TC (Netherlands)

MEMS RELIABILITY

64630D MEMS reliability assessment program: progress to date (Invited Paper) [6463-13]

J. L. Zunino III, D. R. Skelton, U.S. Army RDE Command (USA)

64630E Development of a model for predicting dry stiction in microelectromechanical systems (MEMS) [6463-14]

A. Hariri, J. W. Zu, R. Ben Mrad, Univ. of Toronto (Canada)

OPTICAL MEMS: DESIGN FOR RELIABILITY AND CHARACTERIZATION TECHNIQUES

64630F Optical MEMS: designing for reliability (Invited Paper) [6463-15]

S. Bhattacharya, Indian Institute of Technology, Madras (India)

$64630 \mathrm{G}$ Process engineering and failure analysis of MEMS and MOEMS by digital holography microscopy (DHM) [6463-16]

F. Montfort, Y. Emery, F. Marquet, E. Cuche, N. Aspert, E. Solanas, Lyncée Tec SA

(Switzerland); A. Mehdaoui, A. Ionescu, C. Depeursinge, EPFL (Switzerland)

$64630 \mathrm{H}$ Performance and reliability test of MEMS optical scanners [6463-17]

S. Kurth, Fraunhofer Institute for Reliability and Microintegration (Germany); C. Kaufmann, R. Hahn, Chemnitz Univ. of Technology (Germany); J. Mehner, Fraunhofer Institute for Reliability and Microintegration (Germany); W. Dötzel, Chemnitz Univ. of Technology (Germany); T. Gessner, Fraunhofer Institute for Reliability and Microintegration (Germany) and Chemnitz Univ. of Technology (Germany)

64630l White light interferometric profile measurement system using spectral coherence [6463-18] G.-W. Chang, Y.-H. Lin, Z.-M. Yeh, National Taiwan Normal Univ. (Taiwan) 
64630 J Charging effects in spatial light modulators based on micromirrors [6463-20]

U. Dauderstädt, T. Bakke, P. Dürr, S. Sinning, I. Wullinger, M. Wagner, H. Lakner, Fraunhofer Institute for Photonic Microsystems (Germany)

64630K On the reliability of thermopneumatic actuators with silicon membranes [6463-21]

A. K. Henning, Aquarian Microsystems (USA)

64630L Testing reliability of MEMS materials in liquids [6463-22]

T. P. Kuehn, S. M. Ali, S. C. Mantell, E. K. Longmire, Univ. of Minnesota (USA)

\section{SPECIAL TOPICS IN MEMS II}

64630M Wafer capping of MEMS with fab-friendly metals (Invited Paper) [6463-23]

J. Martin, Analog Devices, Inc. (USA)

$64630 \mathrm{~N}$ Simple measurement technique for resonance frequency of micromachined cantilevers [6463-24]

S. Bhat, E. Bhattacharya, Indian Institute of Technology Madras (India)

646300 Analytical model of a single stage compliant mechanism with flexible lever beam [6463-25]

P. A. Hassanpour, W. L. Cleghorn, Univ. of Toronto (Canada); E. Esmailzadeh, Univ. of Ontario Institute of Technology (Canada); J. K. Mills, Univ. of Toronto (Canada)

64630P A fast model-order reduction algorithm for microelectromechanical devices [6463-26] R. Zhang, P. Zhang, G. A. Jullien, Univ. of Calgary (Canada)

64630Q Development of wireless MEMS sensor for RFID tag and temperature/pressure monitoring [6463-27]

W. Wang, K. Lee, T. Kim, S. Yang, Ajou Univ. (South Korea)

Author Index 
Downloaded From: https://www.spiedigitallibrary.org/conference-proceedings-of-spie on 25 Apr 2023

Terms of Use: https://www.spiedigitallibrary.org/terms-of-use 


\title{
Conference Committee
}

\author{
Symposium Chair \\ Rajeshuni Ramesham, Jet Propulsion Laboratory, California Institute of \\ Technology (USA) \\ Symposium Cochair
}

Albert K. Henning, Aquarian Microsystems (USA)

Conference Chairs

Allyson L. Hartzell, Exponent Inc. (USA)

Rajeshuni Ramesham, Jet Propulsion Laboratory, California Institute of Technology (USA)

Program Committee

Susanne Arney, Lucent Technologies/Bell Laboratories (USA)

Peter Basque, Analog Devices, Inc. (USA)

Enakshi Bhattacharya, Indian Institute of Technology, Madras (India)

Jason O. Clevenger, Exponent Inc. (USA)

Christopher K. Harrison, Schlumberger Ltd. (USA)

Albert K. Henning, Aquarian Microsystems (USA)

John S. McKillop, TeraVicta Technologies, Inc. (USA)

Marco Moraja, SAES Getters S.p.A. (Italy)

Leslie M. Phinney, Sandia National Laboratories (USA)

Olivier N. Pierron II, Qualcomm MEMS Technologies (USA)

David T. Read, National Institute of Standards and Technology (USA)

Herbert R. Shea, Swiss Federal Institutes of Technology (Switzerland)

Srinivas A. Tadigadapa, The Pennsylvania State University (USA)

Danelle M. Tanner, Sandia National Laboratories (USA)

James L. Zunino III, U.S. Army Armament Research, Development, and Engineering Command (USA)

\section{Session Chairs}

Sensors: Applications and Reliability Methodology

Enakshi Bhattacharya, Indian Institute of Technology Madras (India)

RF MEMS and Related Failure Mechanisms

Olivier N. Pierron II, Qualcomm MEMS Technologies (USA)

MEMS Materials Properties

Christopher K. Harrison, Schlumberger Ltd. (USA) 
MEMS Reliability

Jason O. Clevenger, Exponent Inc. (USA)

Optical MEMS: Design for Reliability and Characterization Techniques

Danelle M. Tanner, Sandia National Laboratories (USA)

Special Topics in MEMS I

Peter Basque, Analog Devices, Inc. (USA)

Special Topics in MEMS II

Herbert R. Shea, Swiss Federal Institutes of Technology (Switzerland) 


\section{Introduction}

The reliability, packaging, testing, and characterization of MEMS/MOEMS are of significant importance to the commercialization of these advanced and useful technologies. The objective of this conference is to provide a technical forum for in depth investigations and interdisciplinary discussions. The response to the call for papers has been overwhelming and rewarding.

The Reliability, Packaging, Testing, and Characterization of MEMS/MOEMS Conference is sponsored by SPIE and organized as part of Photonics West 2007, it is part of the MOEMS-MEMS 2007 Micro-Nano Fabrication Symposium, and an education program on MOEMS-MEMS held January 20-25, 2007 in San Jose Convention Center, San Jose, California, USA. SPIE is the premier international forum for presentation of the latest developments associated with MEMS and MOEMS including reliability, testing, packaging, materials, surfaces, and characterization. This conference has been held for several years in row.

In preparing for the conference, 24 high-quality papers were received from researchers in various countries and universities. Nine sessions cover MOEMSMEMS plenary presentations, applications and reliability methodology, RF MEMS and related failure mechanisms, MEMS materials properties, MEMS reliability, optical MEMS design for reliability and characterization techniques, MEMS/MOEMS reliability methodology, MEMS/MOEMS characterization techniques, and special topics in MEMS. We have put together a technical program with seven invited speakers, three plenary speakers from reputed laboratories around the country/globe, and a keynote speaker from Oak Ridge National Laboratory whose presentation is "Receptor free nanomechanical sensing".

We also arranged a panel discussion on "MEMS reliability" for the first time. The panel will be moderated by Jason Clevenger, Exponent Inc. Panel members Peter Basque, Analog Devices; Bill Cummings, Qualcomm; Charles King, Akustica; Danelle Tanner, Sandia National Labs., and Jim Aberson, Colibrys, are highly recognized in this research field.

We would like to personally thank Dr. Danelle Tanner (past reliability conference chair) of Sandia National Labs. and Dr. Al Henning (symposium co-chair) for their unstinting timely support and encouragement. Finally, we would like to thank all the session chairs, co-chairs, and program committee members for their support in organizing this conference so successfully.

\section{Allyson L. Hartzell Rajeshuni Ramesham}


Downloaded From: https://www.spiedigitallibrary.org/conference-proceedings-of-spie on 25 Apr 2023

Terms of Use: https://www.spiedigitallibrary.org/terms-of-use 